\title{
PROFIL PERKEMBANGAN BAKAT KHUSUS PESERTA DIDIK DI KELAS VIII SMP NEGERI 1 SIBERUT SELATAN KABUPATEN KEPULAUAN MENTAWAI
}

\author{
Julianna Sagulu , Ahmad Zaini , Yasrial Candra \\ Program Studi Bimbingan dan Konseling STKIP PGRI Sumatera Barat \\ Juliannasagulu8@gmail.com
}

\begin{abstract}
This reserch is motivated by the presence of student who are less able to understand and remember the lessons given by the teacher, less able to speak indonesian, less able to calculate mathematic lessons, low grade 1 raport card, lazy to participate in school activities, and lack of support, motivation from parent. The purpose of this research is to descibe: 1. Development of special academic talents, 2. Artistic talents, 3. Kinesthetic/psychomotor talents, 4. Social talents. This research was conducted using quantitative descriptive methods. The study pupolation was 150 students. The technique of taking proportional random sampling is 60 students. The research data were obtained through questionnaires and processed using percentage teachiques.Based on the results of research conducted at SMP Negeri 1 South Siberut, Mentawai Islands Regency, the following conclusions can be drawn: 1. Talent for working numbers (Numerical) is in the category of many criteria as many as 5 people $(71,66 \%), 2$. Talents in using laguage there are very many categories as many as 35 people $(58,33 \%), 3$. Talents are able to arrange and are greatly admired in the category quite a lot as many as 14 people $(23,33 \%), 4$. The talents to create songs in 30 minutes is quite a lot category as many as 27 people (45\%). The results of this study are recommended to the supervisor/counselor to assist students in developing the special talents of students at SMP negeri 1 South, Mentwai Island Regency.
\end{abstract}

Keywords: Profile, Development, Special Talents.

\section{PENDAHULUAN}

Bakat seseorang dimiliki sejak ia lahir. Bakat tersebut meliputi bakat akademis dan bakat kemampuan lainnya, seperti seni dan olah raga. Bakat dapat menjadi kemampuan nyata jika dikembangkan dengan baik. Untuk mengembangkan bakat baik diperlukan sifat-sifat yang mendukung. Bakat dan sifat yang dimiliki seseorang dapat menimbulkan minat terhadap sesuatu hal. Bakat, sifat dan minat yang dimiliki seseorang dapat berbeda antara satu orang dengan orang lain, 
http://ejournal.stkip-pgri-sumbar.ac.id/index.php/horizon

perbedaan ini myebabkan cita-cita yang berbeda pula.

Menurut Yusuf (2007:7) bakat adalah bawaan sebagai potensi (potential ability) yang masih perlu dikembangkan dan dilatih/dipelajari. Bakat merupakan potensi yang masih memerlukan latihan dan pengembangan secara serius dan sistematis agar dapat terwujud. Bakat sangat berpengaruh dalam pilihan karir. Dengan mengenal bakat sendiri, seseorang dapat menilai kemampuan dirinya dan dapat meyesuikan diri dengan tuntutan lingkungan atau tawaran dunia kerja.

Mohammad

menyatakan bakat (aptitude) mengandung makna kemampuan bawaan yang merupakan potensi (potential ability) yang masih pengembangan dan latihan lebih lanjut. Karena sifatnya yang masih bersifat potensial atau masih laten, bakat merupakan potensi yang masih memerlukan ikhatiar pengembangan dan pelatihan secara serius dan sistematis agar dapat terwujud.
Setiap individu hendaknya mendapat kesempatan dan pelayanan untuk berkembang secara optimal sesuai dengan kemampuan, kecerdasan, bakat, minatnya, latar belakang dan lingkungan fisik serta sosial masing-masing siswa maka kemajuan belajar siswa yang setingkat (sekelas) mungkin tidak sama.

Salah satu bakat yang ada dalam diir individu yaitu bakat khusus. Bakat khusus merupakan kemampuan individu yang ada dalam diri individu untuk memperoleh pelatihan atau respon beberapa seperti, pengetahuan, keterampilan atau serangkaian tanggapan yaitu kemampuan untuk berbahasa, musik, menghitung, olahraga dan sebagainya. Adanya bakat khusus yang dimiliki individu memang sangat membantu dalam meningkatkan hasil belajanya di sekolah, begitu juga individu yang memiliki bakat khusus tidak dikembangkan dan dilatih secara maksimal maka pada akhirnya tidak 
memberikan hasil yang memuaskan pada diri individu masing-masing

Mudjiran

(2007:750)

menyatakan bakat khusus itu seperangkat sifat yang dianggap sebagai tanda kemampuan individu untuk menerima latihan atau respon, seperti kemampuan berbahasa, musik, berhitung, olahraga dan lain sebagainya.

Munandar

menggolongkan bakat khusus menjadi 5 bagian yaitu bakat akademik khusus, bakat kreatif produktif, bakat estetika/seni, bakat kinestetik/psikomotor, dan bakat sosial. Adanya bakat khusus yang dimiliki oleh peserta didik memang sangat membantu dalam meningkatkan hasil belajarnya di sekolah. Peserta didik yang memiliki bakat khusus tapi tidak dikembangkan dan dilatih secara maksimal dengan baik oleh guru maupun peserta didik itu sendiri pada akhirnya jelas tidak memberi pengaruh positif untuk hasil belajar peserta didik tersebut.
Bakat khusus yang dimiliki oleh peserta didik memang sangat membantu dalam meningkatkan hasil belajarnya di sekolah, begitu juga sebaliknya peserta didik yang memiliki bakat khusus tapi tidak dikembangkan dan dilatih secara maksimal dengan baik oleh guru maupun peserta didik itu sendiri pada akhirnya tidak memberikan hasil yang memuaskan pada peserta didik masing-masing. Mengembangkan bakat dan minat bertujuan agar seseorang belajar atau dikemudian hari bisa bekerja di bidang yang diminatinya dan sesuai dengan kemampuan serta bakat dan minat yang dimilikinya sehingga mereka bisa mengembangkan kapasitas untuk belajar serta bekerja secara optimal dengan penuh antusias.

Masa remaja merupakan masa peralihan dari masa anak kemasa dewasa. Pada periode ini anak mencapai kematangan fisik dan diharapkan pula disertai dengan kematangan emosi dan perkembangan sosialnya. Karena masa peralihan maka remaja pada 
http://ejournal.stkip-pgri-sumbar.ac.id/index.php/horizon

umumnya masih ragu-ragu akan perannya dan menimbulkan krisis identitas. Dalam usaha menemukan jati dirinya dalam arti mengatahui kebutuhan-kebutuhan pribadi serta tujuan yang ingin dicapai dalam hidupnya, maka pengembangan bakat dan minat remaja sangat penting. Dan dalam mengembangkan kompetensinya remaja tetap membutuhkan bimbingan dari orang tua dan lingkungan rumah maupun sekolah.

Jadi, guru dan orangtua juga sangat penting dalam mengembangkan bakat peserta didik. Hal ini dilakukan agar peserta didik yang berbakat dapat mengembangkan potensinya melalui program layanan pendidikan secara khusus. Oleh karena itu, tugas pendidikan adalah mengembangkan kebermaknaan tersebut secara optimal sehingga mereka dapat berkiprah dalam memajukan bangsa dan negara

Berdasarkan observasi yang peneliti lakukan pada saat PLBK Sekolah di SMP Negeri 1 Siberut
Selatan pada tanggal 6 Agustus 2019, peneliti mendapatkan melihat adanya peserta didik kurang mampu memahami dan mengingat pelajara yang diberikan oleh guru, adanya peserta didik kurang mampu berbahasa Indonesia, adanya peserta didik kurang mampu menghitung seperti pelajaran matematika, adanya peserta didik yang malas mengikuti kagiatan di sekolah seperti kepramukaan, keagamaan, kesenian, olahraga (bola basket, sepak bola, dll), adanya peserta didik yang malas mengikuti setiap kegiatan yang diadakan oleh guru di sekolah, dan kurangnya dukungan dan motivasi dari orangtua peserta didik sehingga peserta didik jadi malas.Berdasarkan hasil wawancara salah satu guru Bimbingan dan Konseling yang ada di sekolah SMP Negeri 1 Siberut Selatan pada tanggal 6 Agustus 2020 melalui telepon, peneliti mendapatkan informasi bahwa nilai raport peserta didik semester 1 sangat rendah dibawah KKM. Adanya peserta didik malas mengikuti kegiatan kerohanian, 
http://ejournal.stkip-pgri-sumbar.ac.id/index.php/horizon

adanya peserta didik yang mampu dibidang sepak bola namun nilai olahraga dibawah KKM, adanya peserta didik mampu membuat puisi namun nilai bahasa indonesia rendah, dan adanya peserta didik yang mampu menyanyi namun nilai seni kebudayaan dibawah KKM.

\section{METODE PENELITIAN}

Penelitian kuantitatif menurut Arikunto (2010:10) adalah "Penelitian yang dituntut banyak menggunakan angka, mulai dari pengumpulan data, penafsiran data tersebut, serta penampilan hasilnya". Penelitian ini dilakukan dengan pendekatan deskriptif, yaitu penelitian yang memusatkan perhatian pada permasalahan dan pemecahaan masalah yang ada saat ini. Maka Jenis penelitian ini adalah penelitian deskriptif kuantitatif karena memakai angka-angka, mulai dari pengumpulan data, penjabaran terhadap data tersebut, serta menampilkan hasil data. Secara dedukasi penelitian ini kemudian dideskripsikan oleh peneliti bertolak dari teori-teori umum, kemudian melakukan observasi secara langsung untuk menguji keakuratan data serta keberlakuan teori tersebut untuk ditarik sebuah kesimpulan.Penelitian ini dilaksanakan pada semester ganjil tahun pelajaran 2020/2021. Adapun tempat atau lokasi untuk melaksanakan penelitian ini adalah di SMP Negeri 1 Siberut Selatan Kabupaten Kepulauan Mentawai.

Pengambilan sampel dalam penelitian ini yaitu dengan teknik Proportional Random Sampling. Menurut Yusuf (2005:198) merupakan suatu prosedur atau cara dalam menentukan sampel dengan membagi populasi atas beberapa strata sehingga strata menjadi homogen dan tidak tumpang tindih dengan kelompok lain, atau kelompok antara satu kelompok dengan yang lain bertingkat. Maka sampel dari setiap jumlah seleuruh peserta didik yang ada di kelas, sehingga akan mendapatkan 60 sampel dalam keluruhan kelas. Data dalam penelitian ini diperoleh dari sumber aslinya yaitu data yang diperoleh daripeserta didik di SMP 
Negeri 1 Siberut Selatan Kabupaten Kepulauan Mentawai. Alat pengumpulan data yang digunakan dalam penelitian ini adalah Anget. Menurut Nurkanca (1993:45) Angket atau kuesioner adalah suatu metode pengumpulan data dengan jalan mengajukan suatu daftar pernyataan tertulis kepada sejumlah individu, dan individu yang memberikan daftar pertanyaan tersebut diminta untuk memberikan jawaban secara tertulis pula. Setelah data diperoleh kemudian dilakukan analisis data dengan cara melakukan penskoran terhadap hasil data yang diperoleh kemudian dibuat kesimpulan dari temuan data yang telah dilakukan.

\section{HASIL DAN PEMBAHASAN}

\section{Hasil}

Berdasarkan hasil penelitian tentang profil perkembangan bakat khusus peserta didik kelas VIII SMP N 1 Siberut Selatan Kabupaten Kepulauan Mentawai. Menggunakan item yang valid sebanyak 57 item dengan 9 indikator sebagai batasan masalah yaitu:

$$
\text { Bagaimana profil }
$$

perkembangan bakat khusus peserta didik di Kelas VIII SMP Negeri 1

Siberut Selatan Kabupaten Kepulauan Mentawai.

1. Profil Bakat Khusus Peserta didik kelas VIII SMP N 1 Siberut Selatan Kabupaten Kepulauan Mentawai

Berdasarkan data yang dikumpulkan mengenai Profil perkembangan bakat khusus pada peserta didik kelas VIII SMP N 1 Siberut Selatan Kabupaten Kepulauan Mentawai dapat dijelaskan sebagai berikut:

Tabel 1. Distribusi Frekuensi dan Kriteria Profil Bakat Khusus peserta didik kelas VIII SMP N 1 Siberut Selatan Kabupaten Kepulauan Mentawai.

\begin{tabular}{|c|c|c|c|}
\hline Klasifikasi & Kriteria & $\mathrm{F}$ & $\%$ \\
\hline 239-285 & $\begin{array}{l}\text { Sangat } \\
\text { banyak }\end{array}$ & 3 & 5 \\
\hline $193-238$ & banyak & 54 & 90 \\
\hline 147-192 & $\begin{array}{l}\text { Cukup } \\
\text { banyak }\end{array}$ & 3 & 5 \\
\hline $101-146$ & sedikit & 0 & 0 \\
\hline $57-100$ & $\begin{array}{l}\text { Sangat } \\
\text { sedikit }\end{array}$ & 0 & 0 \\
\hline \multicolumn{2}{|c|}{$\sum$} & 60 & 100 \\
\hline
\end{tabular}

Pada tabel 1 di atas dapat dilihat bahwa Profil perkembangan 
bakat khususpada peserta didik kelas VIII SMP N 1 Siberut Selatan Kabupaten Kepulauan Mentawai tergolong kedalam kriteria sangat banyak sebanyak 3 orang (5\%), kriteria banyak 54 orang $(90 \%)$, kriteria cukup banyak3 orang (5\%) serta pada kriteria sedikit $0 \%$.Jadi dapat disimpulkanProfil bakat khusus pada peserta didik kelas VIII SMP N 1 Siberut Selatan Kabupaten Kepulauan Mentawai tergolong dalam kriteria banyak yang berbakat. Untuk lebih jelasnya dapat dilihat pada grafik berikut ini.

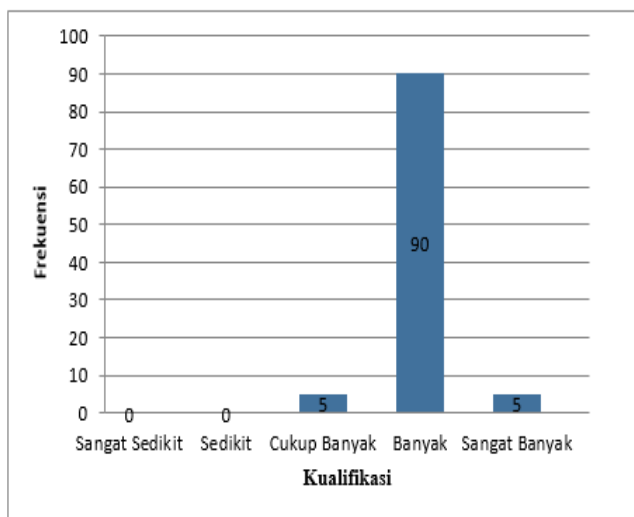

Gambar 1. Grafik Profil Perkembangan bakat khusus pada peserta didik kelas VIII SMP N 1 Siberut Selatan Kabupaten Kepulauan Mentawai

Berdasarkan hasil penelitian yang dilakukan, maka perkembangan bakat khusus pada peserta didik kelas VIII SMP N 1 Siberut Selatan Kabupaten Kepulauan Mentawai tergolong dalam kriteria banyak yang memiliki bakat.

\section{Pembahasan}

Perkembangan bakat khusus adalah merupakan kemampuan individu yang ada dalam diri individu untuk memperoleh pelatihan atau respon beberapa seperti, pengetahuan, keterampilan atau serangkaian tanggapan yaitu kemampuan untuk berbahasa, musik, menghitung, olahraga dan ahli sebagainya. Adanya bakat khusus yang dimiliki individu memang sangat membantu dalam meningkatkan hasil belajanya di sekolah, begitu juga individu yang memiliki bakat khusus tidak dikembangkan dan dilatih secara maksimal maka pada akhirnya tidak memberikan hasil yang memuaskan pada diri individu masing-masing.

Menurut Aliense (2018:89) bakat khusus atau aptitude merupakan kecakapan potensial yang bersifat khusus, yaitu khusus dalam bidang atau kemampuan yang 
dimiliki masing-masing. Bakat (aptitude) mengandung makna kemampuan bawaan yang merupakan potensial (potential ability) yang masih diperlukan dan dikembangkan untuk dilatih agar dapat terwujud. Bakat berbeda dengan kemampuan (ability) yang mengandung makna sebagai daya untuk melakukan sesuatu, sebagai hasil dari pembawaan dan latihan. Bakat juga berbeda dengan kapasitas (capacity) dengan sinonimnya, yaitu kemampuan yang dapat dikembangkan di masa yang akan datang apabila latihan dilakukan secara optimal.

Menurut Yusup (2007:37), 5 aspek perkembangan bakat khusus peserta didik kelas VIII yaitu diantaranya sebagai berikut:

a. Bakat untuk bekerja dalam angkaangka (Numerikal)

Menurut Yusup (2007:37) perkembangan bakat khusus pada peserta didik kelas VIII SMP N 1 Siberut Selatan Kabupaten Kepulauan Mentawai dilihat dari indikator Bakat untuk bekerja dalam angka-angka (Numerikal)tergolong dalam kriteria banyak dengan persentase $71,66 \%$. Berdasarkan hasil analisis data maka dapat dikatakan bawa anak memiliki kemampuan intelegensi yang tinggi dan menunjukan prestasi sekolah yang menonjol.

\section{Sunarto}

(2008:116)

menjelaskan bahwa bakat khusus didefinisikan sebagai kemampuan potensi tipikal, untuk memperoleh pola atau perilaku tertentu yang kurang terdefenisi dengan baik yang terlihat dalam pelaksanaan tugas redpeck di mana individu memiliki sedikit atau tidak ada pelatihan sebelumnya.

Sedangkan Mudjiran (2007:750) menyatakan bakat khusus itu seperangkat sifat yang dianggap sebagai tanda kemampuan individu untuk menerima latihan atau respon, seperti kemampuan berbahasa, musik, berhitung, olahraga dan lain sebagainya.

b. Bakat dalam menggunakan bahasa.

Menurut Yusuf (2007:37) Berdasarkan hasil analisis yang telah dilakukan dilihat bahwa Profil 
perkembangan bakat khusus pada peserta didik kelas VIII SMP N 1

Siberut Selatan Kabupaten Kepulauan Mentawai dilihat dari indikator bakat dalam menggunakan bahasa tergolong kedalam kriteria sangat banyak 58,33\%.Jadi dapat disimpulkan. Profil perkembangan bakat khusus pada peserta didik kelas VIII SMP N 1 Siberut Selatan Kabupaten Kepulauan Mentawai dilihat dari indikator bakat dalam menggunakan bahasa tergolong dalam kriteria sangat banyak.

Menurut Aliense (2018:89) bakat khusus atau aptitude merupakan kecakapan potensial yang bersifat khusus, yaitu khusus dalam bidang atau kemampuan yang dimiliki masing-masing. Bakat (aptitude) mengandung makna kemampuan bawaan yang merupakan potensial (potential ability) yang masih diperlukan dan dikembangkan untuk dilatih agar dapat terwujud. Bakat berbeda dengan kemampuan (ability) yang mengandung makna sebagai daya untuk melakukan sesuatu, sebagai hasil dari pembawaan dan latihan. Bakat juga berbeda dengan kapasitas (capacity) dengan sinonimnya, yaitu kemampuan yang dapat dikembangkan di masa yang akan datang apabila latihan dilakukan secara optimal.

c. Mampu mengarasemen musik dan sangat dikagumi.

Menurut Yusup

$(2007: 37)$

Perkembangan bakat khusus pada peserta didik kelas VIII SMP N 1 Siberut Selatan Kabupaten Kepulauan Mentawai dilihat dari indikator Mampu mengarasemen musik dan sangat dikagumi tergolong kedalam kriteria banyak 48,33\%. Jadi dapat disimpulkan Profil perkembangan bakat khusus pada peserta didik kelas VIII SMP N 1 Siberut Selatan Kabupaten Kepulauan Mentawai indikator Mampu mengarasemen musik dan sangat dikagumi tergolong dalam kriteria banyak.

$$
\text { Suryabrata }
$$
menjelaskan salah satu bakat khusus yang dimiliki oleh seseorang yaitu bakat bidang seni, misalnya 
http://ejournal.stkip-pgri-sumbar.ac.id/index.php/horizon

melukis, olahraga, musik dan lainlainnya. Hal ini juga dilihat dari hasil penelitian yang dilakukan bahwa siswa mampu menunjukan bakat khsus yang ada dalam dirinya.

Bakat berpikir secara kreatifproduktif, kemampuan berkreasi dalam menggabungkan beberapa hal/unsur/gagasan yang lama/sudah ada menjadi baru.

d. Menciptakan lagu dalam 30 menit

Menurut Yusup (2007:37)

Perkembangan bakat khusus pada peserta didik kelas VIII SMP N 1 Siberut Selatan Kabupaten Kepulauan Mentawai dilihat dari indikator dalam Menciptakan lagu dalam 30 menit tergolong kedalam kriteria cukup banyak 45\%. Jadi dapat disimpulkan Profil perkembangan bakat khusus pada peserta didik kelas VIII SMP N 1 Siberut Selatan Kabupaten Kepulauan Mentawai indikator Menciptakan lagu dalam 30 menit tergolong dalam kriteria cukup banyak.

Suryabrata

(2012:176)

menjelaskan salah satu bakat khusus yang dimiliki oleh seseorang yaitu bakat bidang seni, misalnya melukis, olahraga, musik dan lainlainnya. Hal ini juga dilihat dari hasil penelitian yang dilakukan bahwa siswa mampu menunjukan bakat khusus yang ada dalam dirinya. Bakat berpikir secara kreatif-produktif, kemampuan berkreasi dalam menggabungkan beberapa hal/unsur/gagasan yang lama/sudah ada menjadi baru

e. Melukis sangat indah dalam waktu singkat.

Menurut Yusup (2007:37)

Perkembangan bakat khusus pada peserta didik kelas VIII SMP N 1 Siberut Selatan Kabupaten Kepulauan Mentawai dilihat dari indikator melukis sangat indah dalam waktu singkat tergolong kedalam kriteria banyak 55,55\%. Jadi dapat disimpulkan. Profil perkembangan bakat khusus pada peserta didik kelas VIII SMP N 1 Siberut Selatan Kabupaten Kepulauan Mentawai indikator Melukis sangat indah dalam waktu singkat tergolong dalam kriteria banyak. 
http://ejournal.stkip-pgri-sumbar.ac.id/index.php/horizon

Menurut Asrori (2011:83) ada beberapa yang perlu dilakukan untuk mengembangkan bakat khusus individu, yaitu mengembangkan situasi dan kondisi yang memberikan kesempatan bagi anak-anak dan remaja untuk mengembangkan bakat khususnya dengan mengusahakan dukungan baik psikologis maupun fisik.

f. Bakat dalam menggunakan keterampilan teknik.

Menurut Yusup (2007:37)

Perkembangan bakat khususpeserta didik kelas VIII SMP N 1 Siberut Selatan Kabupaten Kepulauan Mentawai indikator bakat dalam menggunakan keterampilan teknik tergolong kedalam kriteria banyak 55\%.Jadi dapat disimpulkanProfil perkembangan bakat khususpeserta didik kelas VIII SMP N 1 Siberut Selatan Kabupaten Kepulauan Mentawai indikator bakat dalam menggunakan keterampilan teknik tergolong dalam kriteria banyak.

Menurut Nento (2019:27) yang perlu diperhatikan dalam pengembangan bakat khusus yaitu perhatian. Setiap individu adalah unik karena itu setiap bakat perlu memperoleh perhatian khusus. Sistem pendidikan yang menggunakan pola penyeragaman kurang baik untuk digunakan. Serta Motivasi. Bantu anak dalam meyakini dan fokus pada kelebihan dirinya agar anak lebih percaya diri. Dan tanamkanlah rasa optimis kepada mereka bahwa mereka bisa mencapainya.

g. Mahir dalam melakukan negosiasi.

Menurut Yusup (2007:37)

Perkembangan bakat khusus peserta didik kelas VIII SMP N 1 Siberut Selatan Kabupaten Kepulauan Mentawai indikator mahir dalam melakukan negosiasi tergolong kedalam kriteria banyak 55\%. Jadi dapat disimpulkan Profil perkembangan bakat khusus peserta didik kelas VIII SMP N 1 Siberut Selatan Kabupaten Kepulauan Mentawai indikator bakat dalam menggunakan keterampilan teknik mahir dalam melakukan negosiasi tergolong dalam kriteria banyak.

Menurut Nento (2019:27) yang perlu diperhatikan dalam 
pengembangan bakat khusus yaitu lingkungan. Lingkungan juga ikut mempengaruhi perkembangan bakat anak. Maka diusahakan anak selalu dekat dengan lingkungan yang mendukung bakat anak. Selain itu perlu adanya kerjasama. Kerja sama antara orangtua, guru maupun anak sangat diperlukan mengingat waktu anak di sekolah hanya sedikit dan waktu yang anak luangkan di rumah lebih banyak. Serta contoh teladan yang baik. Mengingat sikap anak yang selalu meniru, maka teladan yang baik sangat diperlukan.

h. Mahir dalam komunikasi.

$$
\text { Menurut Yusup }
$$

Perkembangan bakat khusus peserta didik kelas VIII SMP N 1 Siberut Selatan Kabupaten Kepulauan Mentawai indikator antisispasi tergolong kedalam kriteria banyak $55 \%$. Jadi dapat disimpulkan Profil perkembangan bakat khusus peserta didik kelas VIII SMP N 1 Siberut Selatan Kabupaten Kepulauan Mentawai indikator bakat dalam menggunakan keterampilan teknik mahir dalam melakukan negosiasi tergolong dalam kriteria banyak. Mahir dalam komunikasi adalah bagian dari perkembangan bakat khusus aspek afektif.

Menurut Samio (2018:40) implikasi pegembangan bakat khusus anak dan remaja terhadap penyelenggaraan pendidikan yaitu: dalam suasana yang aman secara psikologis, anak dan remaja merasa nyaman untuk mengungkapkan dan megekspresikan bakatnya. Pendidikan hendaknya berfungsi untuk mengembangkan bakat khusus anak dan remaja berfungsi sebagai media pengembangan dan pembinaan bakat anak dan remaja. Pengenalan bakat dan upaya pengembangannya membantu anak dan remaja untuk menentukan pilihan yang tepat dan meyiapkan dirinya untuk mencapai tujuan dan karier kehidupannya

i. Memberi Mahir dalam kepemimpinan.

$$
\text { Menurut Yusup (2007:37) }
$$

Perkembangan bakat khususpeserta didik kelas VIII SMP N 1 Siberut Selatan Kabupaten Kepulauan Mentawai indikator memberi mahir 
http://ejournal.stkip-pgri-sumbar.ac.id/index.php/horizon

dalam kepemimpinan tergolong kedalam kriteria cukup banyak banyak 55\%. Jadi dapat disimpulkan Profil perkembangan bakat khusus peserta didik kelas VIII SMP N 1 Siberut Selatan Kabupaten Kepulauan Mentawai indikator memberi mahir dalam kepemimpinan tergolong dalam kriteria cukup banyak. Memberi mahir dalam kepemimpinan adalah bagian dari perkembangan bakat khususaspek kognitif.

$$
\text { Mudjiran }
$$

mengemukakan bakat bersifat potensial dan memerlukan pegembangan. Untuk pengembangan bakat ada sejumlah hal yang harus dilakukan antara lain:Perkaya anak dengan macammacam pengalaman dan membangun motivasi belajar. Dengan cara ini anak akan dapat menemukan dibidang bakatnya. Dorong atau rangsanglah anak untuk meluaskan kemampuannya, setelah anak mengarang, anjurkan dia untuk menggambarkan.
Sedialahkan sarana yang memadai untuk pengembangan anak.

Berdasarkan uraian di atas, berikut ini akan disajikan rekapitulasi profil perkembangan bakat khusus peserta didik di kelas VIII SMP Negeri Siberut Selatan Kabupaten Kepulauan Mentawai berdasarkan, persentase dan kriteria.

\section{KESIMPULAN}

Berdasarkan hasil penelitian tentang Profil perkembangan bakat khusus pada peserta didik kelas VIII SMP N 1 Siberut Selatan Kabupaten Kepulauan Mentawai beradapada kategori banyak dengan persentase 90\%. Adapun profil perkembangan bakat khusus peserta didik dapat simpulan sebagai berikut:

1. Perkembangan bakat akademik khusus peserta didik berada kategori banyak sebanyak 5 orang $(71,66 \%)$.

2. Perkembangan bakat kinestetik / psikomotorik peserta didik berada kategori sangat banyak sebanyak 35 orang $(58,33 \%)$.

3. Perkembangan bakat seni peserta didik berada kategori cukup 
Publish by: Library of STKIP PGRI Sumatera Barat

E-ISSN : 2775-5770

Vol. 1 No. 2 (Mei 2021) (204-217)

http://ejournal.stkip-pgri-sumbar.ac.id/index.php/horizon

banyak sebanyak 14 orang $(23,33 \%)$.

4. Perkembangan bakat sosial peserta didik berada kategori cukup banyak sebanyak 27 orang $(45 \%)$.

5. Perkembangan bakat kreatifproduktif berada kategori sangat sedikit $(0 \%)$

\section{DAFTAR PUSTAKA}

Asrori ,M. (2011). Psikologi Perkembangan Peserta Didik. Jakarta: PT Bumi Aksara.

Arikunto, S. (2010). Prosedur Penelitian, suatu Pendekatan Praktik. Jakarta: Rineka Cipta.

Mudjiran. (2007). Buku Ajar Perkembangan Psera Didik. Padang: UNP Press.

Munandar, U. (2008). Penembangan Kreativitas Anak Berbakat. Jakarta: Rineka Cipta.

Nento , A. (2019). Faktor-faktor yang Mempengaruhi
Perkembangan Bakat Khusus Peserta Didik di SMP Negeri 1 Luwek. Jurnal Linear vol.03.NO.05. ISSN: 25498657, 26.

Nurkancana, W. (1993). Pemahaman Individu. Surabaya: Usaha Nasional.

Semio. (2018). Aspek-aspek Pertumbuhan dan Perkembangan Peserta Didik. Best Jurnal (Biology Education Science \& Teknologi). Vol.1.No.02. ISSN: 2614-8046, 40.

Sunarto, H. (2008). Perkembangan Peserta Didik. Jakarta: Rineka Cipta.

Suryabrata. (2012). Metodologi Penelitian. Jakarta: PT Raja Grafindo Persada.

Yusuf, A. (2005). Metode Penelitian (Dasar-dasar Penyelidikan Ilmiah). Pdang: UNP Press.

Yusuf, S. (2007). Metode Penelitian. Padang: UNP Press. 